\title{
Selected Elements of Animated Nature AsSociated With THE BIRTH OF Jesus IN THE BULgarian Oral Culture and Apocryphal Narratives
}

Animals have earned a permanent place in the history of thought, culture and art of $\mathrm{man}^{1}$, and the natural sciences are no longer the only ones to examine the relationship between people and the world of fauna. Scientific discourse addresses the presence of animals in religion, philosophy, literature, and arts, with particular emphasis on those components of culture which may include common perceptions of selected species, probably representing the consequences of prehistoric thinking, currently found in works of literature, philosophy, and folk traditions. This article attempts to extract textual and extratextual planes on which representatives of fauna made their mark in the folklore of the South Slavs, mainly Bulgarians; in their oral literature, rituals, and beliefs, juxtaposed with selected Apocrypha, primarily from the Protoevangelium of James, confronted with the Scripture. The analysed texts relate to the birth of Christ in Bethlehem and placing him in a manger - the events of Night of Bethlehem and the flight of the Holy Family to Egypt.

The Gospel narrative concerning the circumstances of Christ's birth is widely reflected in the visual arts, represented by various works created over the centuries, from the Early Christian era to the present time. Medieval painting, inspired by the Bible, lives of the saints, hagiographic legends, and apocryphal narratives, had a considerable role in imprinting the Nativity scene in the minds of the faithful. The oldest iconographic ideas were generally limited to the figure of Christ in the grotto, accompanied by farm animals. In time, the image was expanded with other figures, such as the Mother of God, St. Joseph, bowing shepherds, Magi from the East, and the angels. As the scene grew more and more complex, the difference between the iconography of the East (Palestine, Byzantium) and of the West became increasingly more pronounced - above all, the Italian artists moved the Nativity scene from a grotto to a shed ${ }^{2}$.

Themes of the birth of Christ are also found in the Bulgarian sacred art, for example in the extensive iconographic collection of the Church of the Nativity in the village of Arbanasi, which includes a seventeenth-century icon depicting the

\footnotetext{
${ }^{1}$ E. Sakowicz, Znaczenie zwierząt w religiach świata, FT 6, 2005, p. 23.

2 J. KŁosı́́sKa, Sztuka bizantyńska, Warszawa 1975, p. 188-202.
} 
events of Night of Bethlehem. The main part of the composition by an unknown author depicts the grotto, the Child lying on a rectangular, stone bed, Mary sitting next to him, and Joseph receiving gifts from the Three Magi. In the scene animals are also present - ox and a donkey, as well as shepherds. Moreover, in the upper part of the painting, there are angels descending from opened heaven, the Bethlehem Star, and flocks grazing in the mountains. The Christmas theme is also present in the Bulgarian oral culture. Folk prose works relating the story of Jesus' birth are found in a relatively little varied form, placing the Mother of God and the saints in the centre of events (the legend of the encounter with St. Tryphon, the theme of search for the godfather to the child), or give way to other themes of apocryphal origin (such as the stories about the Cross Tree or the Theotokos visiting hell). The theme of the Nativity of the Lord appears more frequently in Bulgarian folk poetry, mainly in songs performed during the Christmas carolling. The query yielded results in the form of eleven folk texts, which have been divided into two groups: prose works (legends and folk tales, where individual variants are marked with the symbol $\mathbf{L}$ and an ordinal number as a subscript) and poems (carolling songs, variants marked with the symbol $\mathbf{P}$ and ordinal number as a subscript). Within both these groups, I use chronological order, i.e. they are arranged according to the date of publication of the text (due to lack of information from the collector/recorder, it is impossible to take into account the date the variant was written). The description of each variant begins with a full bibliographic description or abbreviation of the name of the collection with the volume number, year of publication, page number and title of the work - if one exists. In the absence of a title, I quote the beginning of the text (for poetic works - the first verse). If the work was published again, usually in accordance with the new language standard, also I provide the bibliographic description and the title of the text. Then, I describe the variant according to the following model:

I. Geographical location of the variant.

II. Biographical information on the collector and teller (if their names are given or possible to decipher - if not, they are marked with an asterisk).

III. Summary of plot.

IV. Preliminary comment on the location of the text within the collection, collector's remarks, for prose texts -presence of the type in classifications, possible contaminations, and so on.

\section{LEGENDS AND FOLKLORE}

$\mathrm{L}_{1}$ - СНУНК 2, 1890, p. 162, о. 4, Едно време, когато бегала Св. Богородица c Господ от иифутите...

I. Veliko Turnovo area, North-Central Bulgaria. 
II. Recorded by Tsani Gintchev (1835-1890), Bulgarian writer, activist of the national revival and publicist.

III. Mother of God with Jesus are hiding from the Jews in a cave. A spider appears and weaves a web blocking the entrance. Then, a pigeon comes and lays an egg in the spider web. The Jews arrive but, seeing cobwebs and the pigeon egg, they do not enter the cave, because they are convinced that no one has had been there in a long time. Mother of God blesses the spider - from now on, it is capable of weaving webs each day and living with people in their homes, and the pigeon - the bird lays eggs and hatches them every month.

IV. The text in section Тблкувания на природни явления, разни народни вярвания и прокобявания (Explanations of natural phenomena, various folk beliefs and prophesies ${ }^{3}$ ). In the International Classification of fable themes: ATU 750E Flight to Egypt, ATU 967 The Man Saved by a Spider Web, Catalogue of Bulgarian folk tale: БФП 967 Спасени благодарение на паяжина.

$\mathrm{L}_{2}$ - СНУНК 2, 1890, p. 162, о. 6, Едно време, когато Божа майка родила млада Бога...; А. Георгиева, Когато Господ ходеше по земята. 77 фолклорни легенди и тәлкувания, София 1994, р. 75, Богородица благословя кравата и [проклина] катьрицата

I. Veliko Turnovo area, North-Central Bulgaria.

II. Recorded by Tsani Gintchev (1835-1890), Bulgarian writer, activist of the national revival and publicist.

III. Virgin Mary is hiding the New-born in a manger. A cow covers the Baby with straw, and a mule female is trying to expose Him. Mother of God blesses the cow with fertility and curses the mule - from now on the animal is infertile.

IV. Text placed in section Тълкувания на природни явления, разни народни вярвания и прокобявания (Explanations of natural phenomena, various folk beliefs and predictions). The International Classification of fable themes: ATU 750E Flight to Egypt, ATU 967 The Man Saved by a Spider Web, Catalogue of Bulgarian folk tale: БФП 967 Спасени благодарение на паяжина.

\section{$\mathrm{L}_{3}$ - СНУНК 13, 1896, p. 184, №. 4, Сретение Господне или очищението на} Св. Богородииа; БНПП 7, р. 207-208, Трифон Зарезан и Света Богородииа I. Veliko Turnovo area, North-Central Bulgaria.

II. Recorded by rote Petko Ratchev Slaveykov (1827-1895), Bulgarian writer, activist of the national revival and publicist. Told by baba Stana, wife of Petr Bosadzhaya.

III. On her way to church, Mother of God meets St. Tryphon, who ridicules her for her unmarried status. Mother of God comes home and, embarrassed, rejects the child. Earlier, however, she advises Tryphon's sister to take bandages and go to see her brother. The latter, unpleasantly surprised by the visit and wanting

\footnotetext{
${ }^{3}$ Names of sections have been translated by the author of this article.
} 
to show her how to cultivate vines, cut off his own nose. Meanwhile, the Mother of God receives a visit from animals who plead for little Jesus, but she rejects the child. Finally, Mother of God, moved by the love that a frog shows to its ugly child, returns to caring for her son.

IV. Variant placed in section Приказки за черковни лиияа и явления (Fables about clergy and phenomena).

The text published after the death of the collector, as noted in the table of contents. In a footnote, P.R. Slaveykov explains that baba Stana did not hail from Turnovo, but from another, distant place (name not given). The International Classification of fable themes: ATU 247 Each Mother Likes Her Own Children Best (contamination), a catalogue of Bulgarian folk tale: БФП * 247А Жабата нарекла жабчето си хубчо (contamination).

$\mathrm{L}_{4}$ - Български предания и легенди, гатанки, пословици и благословии, ed. А. Калоянов, Велико Търново 2000, p. 119-120, Защо жабата е благословена

I. Village Kolayjidere, Komotini area, today north-eastern Greece.

II. Unknown.

III. Mother of God gives birth to Jesus, but she does not want to take care of the child. People and animals ask her to change her mind. A frog arrives with its own child, but the Mother of God ridicules it. The amphibian addresses its offspring tenderly and returns home. Then the Mother of God, moved by the frog's motherhood, sees her own error and embraces Jesus. God bestows his blessing upon the frog: from now on a dead frog, unlike other animals, does not have an unpleasant odour.

IV. Variant placed in section Легенди за потекло (Legends about the origin). According to a note accompanying the legend, it was published for the first time in the journal Родопски напредък in 1909, however, the text is missing from that issue. The International Classification of fable themes: ATU 247 Each Mother Likes Her Own Children Best, catalogue of Bulgarian folk tale: БФП * 247A Жабата нарекла жабчето си хубчо.

\section{CAROLLING SONGS}

$\mathrm{P}_{1}$ - К.А. Шапкарев, Сборник от български народни умотворения, Pars 1, Простонародна българска поезия или български народни песни, София 1891, p. 82, о. 74, Сива-сива голобица; Народни празднични песни, еd. Д. Осинин, електронно издание, ЕИ LiterNet, Варна 2000, Сива гълъбица

I. Ohrid area, today south-western Macedonia.

II. Recorded by Kousman Atanasov Shapkarev (1834-1909), Bulgarian folklorist and revival activist.

III. A grey dove, which flew from the Danube, praises the young God and promises to serve Him. 
IV. Text placed in section Обрядни песни. Божични (Ceremonial songs. Christmas) with a note На Бъдник в Охрид (коледа).

Song was referenced four footnotes: 1 . Comment referring to the adjective сива (BGR. grey, ashen), which is to be interpreted as the colour of the bird, here: dove-Mother of God, and should not be confused with the god Shiva. 2. Comment relates to the other variants of the song, known in Ohrid, in which there is an additional verse, repeated as a chorus, for example Коледе, бабо, коледе. 3. Comment refers to a variant of the song published by Georgi Sava Rakovski, in which instead of words бел Дунав (Bulgarian white Danube) Бейбунар was recorded. Although there is a place by such name, K.A. Shapkarev considered Бейбунар to be a mistake of the recorder, or invention or linguistic sloppiness of performers of the song. 4. Comment refers to the verse златна чаша и каната (Bulgarian golden сир and pitcher), which is also found in the Christmas Eve songs in the second volume of Stefan Verkovićs's collection Веда славян.

$\mathrm{P}_{2}$ - СНУНК 2, 1890, р. 162, о. 1, Буи, буи, Коледо, нека буи, Коледо; БНПП 2, No. 5, Долетяха два гълъба

I. Lokorsko Village, Sofia area, Western Bulgaria.

II. Recorded by Tsvetan Vulchanov*, a teacher from the village of Lokorsko, amateur folklorist; sang by L. Vulchanova*.

III. A pair of pigeons bring walnut twigs to a goldsmith to make golden keys. Using the keys, the birds open the heavens and the earth, and all creatures rejoice in the coming of Jesus.

IV. The text in section Песни периодически и религиозни. Коледни песни (Seasonal and religious songs. Carolling songs), with a note На малото коледо. Song performed on December 24 on Christmas Eve (Bulgarian Малка коледа). According to the final passage - a song dedicated to the host. It includes wishes of good health for the household.

\section{$\mathrm{P}_{3}$ - СНУНК 7, 1892, p. 15, о. 20, Зазори се, Божнеле, зорна зора}

I. Song heard in the village Yakhetype (today Vetrino) Provadean Plateau, Varna area, North-Eastern Bulgaria.

II. Recorded by At. Maltchev*, a teacher.

III. Mother of God is walking through a forest looking for a place where she could give birth. When Young God comes into the world, Mother of God ties a golden cradle onto a golden hornbeam, which lulls the baby to sleep. Then a cuckoo starts singing. Mary tells the bird to be silent from the feast of St. John until Easter.

IV. Text placed in section Песни периодически и религиозни. Коледни обичаи, песни и благостовии (Seasonal and religious songs. Carolling customs, songs, and blessings). 
$\mathrm{P}_{4}$ - СНУНК 7, 1892, p. 15, о. 22, Закукува, Божнеле, кукувица; БНПП 5, No. 56, Божа майка и кукувииа 2

I. Song heard in the village Yakhetype (today Vetrino) Provadean Plateau, Varna area, North-Eastern Bulgaria.

II. Recorded by At. Maltchev*, a teacher.

III. In the forest, a cuckoo is singing. Mary fears that the bird might wake her child. The cuckoo explains that it just wants to wake shepherds whose flock have wandered away. Then, the Holy Mother calls St. John, who is meant to first make cornel-tree whips and use them to rush the flock, then milk the sheep and prepare sirene to feed travellers.

IV. Text placed in section Песни периодически и религиозни. Коледни обичаи, песни и благословии (Seasonal and religious songs. Carolling customs, songs, and blessings). According to a footnote to a more recent edition of the text a carolling song sung to the hostess.

$\mathrm{P}_{5}$ - СНУНК 8, 1892, p. 11, о. 5, Префргкнала, Божне ле, пәстра птичка; Сенки из невиделица. Книга на българска народна балада, еd. Б. Ангелов, Хр. Вакарелски, електронно издание, ЕИ LiterNet, Варна 2005, Божа майка проклина кукувицата

I. Song heard in the village of Krumovo, Varna area, North-Eastern Bulgaria.

II. Recorded by V.S. Stamenov*.

III. Virgin Mary hangs a cradle with the Child on a tree. A cuckoo sings loudly and wakes the baby. Mary curses her; from now on, the cuckoo does not make its own nest, but lays its eggs in other birds' nests instead, where they are recognised as alien and rejected.

IV. Text placed in section Песни периодически и религиозни. Коледни обичаи, песни и благословии (Seasonal and religious songs. Carolling customs, songs, and blessings). According to a note by the recorder and the last two verses a song sung to the household. Includes wishes of good health.

\section{$\mathrm{P}_{6}$ - Български народни песни, записал полк. Г. Янков от Елена В. Янкова,} Пловдив 1908, p. 207-208, Божа майка проклева кукувичката

I. Bessarabia.

II. Recorded by Georgi Yankov (1855-1920), colonel, lawyer, folklorist, sung by Elena Vulkova Yankova (1825-1901), Georgi's mother.

III. Mother of God is angry with the cuckoo which tries to wake sleeping shepherds. Their flocks have wandered onto the Sultan's land. The bird does not understand Mary and is cursed.

IV. Text placed in section Обредни или периодически песни. Коладни песни (Seasonal or ritual songs. Carolling songs). 
$\mathrm{P}_{7}$ - СНУН 60.1, 1993, p. 385-386, No. 510, Божа майка проклина трепетликата и кукувицата

I. Song heard in the village of Ivan Vasovo, Plovdiv area, central Bulgaria.

II. Recorded by Oleg Mladenov, contemporary Bulgarian folklorist, sung by Dela Petkova Arova, 65-year-old farmer woman, with one year of primary school.

III. Mary asks St. Peter to sing her a Christmas Eve song. In anticipation of the music, all nature becomes silent and still. Only aspen and cuckoo cannot respect the solemn moment, so the Mother of God curses them. The tree shall grow in dark, abandoned, barren places, and the bird can only sing in the spring.

IV. Text placed in section Религиозно-легендарни песни и балади (Religious and legend songs and ballads). The song was recorded on July 24, 1975. According to a footnote in the text - the song was performed during the evening feast by carollers.

The variants of prose texts (legends and folk tales) listed above can be classified as etiological - explaining the origin, telling of the circumstances of how certain elements of reality came to be. According to the classification of A. Georgieva ${ }^{4}$, etiological folk legends are divided into two groups, with the division criterion based on phenomena to the creation of which they refer. In the first group, there are legends about the origin of the world and natural phenomena, and so these stories relate to the creation of elements of nature. In the second group, there are stories about the origin of social phenomena and practices related to human life, explaining the genesis of elements of culture. Folk legends about Theotokos blessing selected species of animals and cursing others belong to one of the subgroups of the first type: they are stories explaining the characteristics of the elements or phenomena of nature; plants, animals, or man. They do not address the circumstances that gave rise to the species, but explain its particular qualities or features relevant to culture. Mother of God gives the spider the ability to weave its web quickly, and the pigeon and the cow receive the gift of fertility, which is taken away from the mule $\left(\mathrm{L}_{1}, \mathrm{~L}_{2}\right)$ In the legends, there is no information on the characteristics of those animals before the blessing. It is not known whether the cow had always calved every year or if the pigeon had laid eggs every month. The blessing bestowed upon the frog $\left(\mathrm{L}_{4}\right)$ remains somewhat debatable in light of herpetology, although it can be read as a singular exaltation of the frog. In hagiographic stories, a similar description can be found of the way the body of a holy person behaves; it does not rot, it glows, and it can even produce floral scent, or other pleasant aromas.

The story of the meeting of the Mother of God and St. Tryphon $\left(\mathrm{L}_{3}\right)$ contains several elements of etiological character, but relating to the other type of story - namely culture-oriented. In addition to the memories of the special participation of the frog in consoling the offended Mary, the legend refers to the order of

\footnotetext{
${ }^{4}$ Cf. А. ГЕоргИЕвА, Етиологичните тегенди в българския фолклор, София 1990, p. 30-38.
} 
the Orthodox calendar, according to which the Feast of Saint Tryphon (February 1 or 14) precedes the Presentation of the Lord (February 2 or 15). The legend of St. Tryphon qualifies for a group of stories explaining not only the origins of ritual practices, but also highlighting the need to comply with certain rules. In this case, it is Mother of God herself who does not observe the 40-day ban on entering the church, which makes her the subject of criticism and punishment.

The first two texts represent the type ATU 750E Flight to Egypt (section Religious Tales) recorded in the International Classification, which covers a comprehensive set of stories about the Holy Family travelling to Egypt and a series of miraculous events that occur on the way. As M. Zowczak writes:

Tales of the flight from Egypt are based on a standard pattern explaining the diversity of trees, properties of stone, qualities of cuckoos, oxen and horses, as well as why the spider is untouchable. These are typical stories of blessings and curses, or grace and punishment granted by the hand of Providence. ${ }^{5}$

The travellers receive assistance from trees, plants, fruit, birds, animals, people, elements of inanimate nature, such as a river, or objects - a horseshoe, and helpers always receive a blessing in return. At this number, the catalogue of Bulgarian folk tale lists plots related to the sacrifice of Abraham, while it quotes the type БФП 967 Спасени благодарение на паяжина (section Fairy-tales - Novelle), featuring several variants of the story of how Mary and Jesus were hiding from the Jews in a cave and were rescued by a spider, which wove a web to cover the entrance. The International Classification also takes note of the type ATU 967 The Man Saved by a Spider Web (section Realistic Tales - Novelle), with the story of Mary and Christ among other plots revolving around escape. In $\mathrm{L}_{1}$, the spider is not the only one to provide assistance to the fleeing, but also the dove: Бужа майка благословила паяка да може за един ден да си уплита паяджината, да се въди из къщите, дето живеят хора, а гълъба - да несе и да мәти секи месеи. According to a popular saying, a house where pigeons lay eggs will be deserted because it will be haunted by misfortune ${ }^{6}$. The story of the escape of Virgin Mary from the Jews used the theme of a bad omen in a different way - a seemingly deserted cave provides rescue to the fleeing.

$\mathrm{L}_{2}$ features a familiar image, found in iconographic representations of the Nativity of the Lord: the Baby is lying in a manger, with farm animals present in a stable standing by. Here, the course of the story is quite different, because it is only the cow that shows kindness to the Child and covers Him with straw, while the mule is trying to expose Jesus by taking straw away: Кравата заривала с носа

\footnotetext{
${ }^{5}$ M. Zowczak, Biblia ludowa. Interpretacje wątków biblijnych $w$ kulturze ludowej, Wrocław 2000, p. 263.

${ }_{6}^{6}$ Д. МАРинов, Избрани произведения в пет тома, vol. I, pars 1, Народна вяра, София 2003, p. 145.
} 
млада Бога, катърииата го откривала. As noted by A. Georgieva ${ }^{7}$, the cow helps the positive heroes - Jesus and the Virgin Mary - keeping in accordance with accepted standards of morality. In the text, there is no mention of the Mother of God escaping with Child, but it can be assumed that the mule sides with the antagonists - Jews seeking new-born babies, and this is why it wants to expose Christ and give Him to death by their hand. As a result of their deeds, one of the animals is rewarded - from now on the cow is made fertile, every year giving birth to a calf, sometimes even two. In contrast, the other animal - the mule - is severely punished with infertility. The folklore text replaces the biblical species of farm animals with their female counterparts: the ox, symbolising the Chosen People in the Scripture, has become a fertile cow, while the donkey has been treated less kindly by folk culture, which - instead of making a reference to its actual qualities: humility and gentleness - associates it with the ass from the Book of Ezekiel ${ }^{8}$ symbol of debauchery, and punishing the mule, zoological hybrid resulting from a mare mating with a male donkey (jack), with infertility ${ }^{9}$.

In $\mathrm{L}_{3}$, animals appear in more than a month after the birth of Jesus, but their arrival is quite important. Mother of God goes to the church to observe the ritual of purification, but on the way there she meets St. Tryphon who, while he is cutting vines, ridicules her as an unmarried mother. Virgin Mary returns home crying and decides to hide Jesus. Then all the animals and wee beasties ${ }^{10}$ visit her begging her not to abandon the child: Това като дозели от само себе си (по инстинкт) всичките зверове и гадини, всичките ходели да и се молят и да я предумват да не слуша развратните хора и да не прави тъй, да си оставя детето си Христа Бога. Among those animals, there is a frog with its own ugly offspring, which, however, in the frog's eyes is the most beautiful. Upon hearing how tenderly the frog addresses its offspring (хайде, хубче, да си идем), Virgin Mary gains confidence, her delight in Christ returns, and the next day she went to the church to pray. This story was recorded in the catalogue of Bulgarian folk tale under number ${ }^{\star 247 A ~ Ж а б а т а ~ н а р е к л а ~ ж а б ч е т о ~ с и ~ х у б ч о ~(s e c t i o n ~ C a r t o o n s ~}$ animal - birds and fish). The International Classification of fable themes lists the type ATU 247 Each Mother Likes Her Own Children Best (section Animal Tales). The theme of learning motherhood from the frog does not exist independently, but appears as one of the episodes of the legend of the meeting of Virgin Mary with St.

\footnotetext{
${ }^{7}$ А. ГеОРГИЕВА, Действието чудо в етиологичните легенди, БФ 12.2, 1986, p. 11-19.

${ }^{8} \mathrm{Ez} 23,20$. All biblical quotations and references from: The Holy Bible - Revised Standard Version Catholic Edition, London 1966.

${ }^{9}$ The dychotomia of the symbolical character of the biblical ass. cf. M. LuRKer, Stownik obrazów i symboli biblijnych, trans. K. Romaniuk, Poznań 1989, p. 162-163.

${ }_{10}$ Text in English based on the Polish translation: Złota moneta za słowo. Bułgarskie bajki i legendy ludowe, ed. G. Minczew, Łódź 2006, p. 237.
} 
Tryphon, represented in the Bulgarian folklore by an extensive collection of prose texts ${ }^{11}$.

The key episodes of the legend clearly have moralistic overtones. Mother of God decides to go to church the day earlier (February 1) that the appropriate date (February 2): Света Богородииа, наместо да си чете на втори (sесопd) февруари, както бил срокът на очищението, решила да си чете на първи (first) февруари един ден по-напред, so she attempts to make changes in the liturgical calendar, acting against the traditional folk custom of the 40-day postpartum confinement. She meets St. Tryphon, whose words and abusive behaviour become her punishment, but ultimately restore the established order. Then St. Tryphon performs self-mutilation, which is the result of Mary's curse, even though the moment of the curse is not specified in the text. St. Tryphon is punished for inappropriate behaviour towards the divine person, but also in part for his malignant self-confidence, because at the time he suffered his injury he was smugly teaching his sister how to clip vines. The moral is revealed at the end of the legend, when the amphibian teaches Mother of God how to love her own child. The legend lacks the blessing for the frog scene, which - considering the multitude of good deeds (dissuading Mary from abandoning her child, restoring Mother of God the status of the person who should not be worried about what people are saying, and finally teaching her motherhood) - should be bestowed upon it. This part of the story is mentioned in $\mathrm{L}_{4}$, together with an explanation as to why the body of a dead frog does not have a bad smell. Here, it is God himself who grants the reward, and the amphibian is depicted as a sensitive and modest creature, although in the eyes of the Mother of God - initially wretched, unremarkable, and mocked: $y-y$, виж и това ме моли и на детенцето си казва сребърно златче! Не, аз съм крива! - И си взела детението.

In the beliefs of the Slavs, the frog has had a special place from the earliest times ${ }^{12}$ - folk tradition prohibits killing frogs outside of rites, because the animal has the grace of Virgin Mary, and it is also responsible for the right amount of rain in the spring and summer months (hence the belief that killing frogs without a proper reason can bring drought). Frogs, whether in the form of costumes, actual animals - alive or killed specifically for this purpose - appear in the rites nenepyda and Герман ${ }^{13}$, which are meant to bring rain. Dialectal rite names (Perepuna, Peperuna, Peperuga etc. $)^{14}$ sound similar to the name of the Perun - the mythical god of lightning and thunder ${ }^{15}$. A. Gieysztor calls the girl participating in the rite

\footnotetext{
${ }^{11}$ С. Г. ВълчиновА, Между езичество и християнство: свети Трибон в българските народни представи, БФ 15.2, 1989, р. 15-25.

${ }^{12}$ И. ГЕОРГИЕВА, Българска народна митология, София 1993, р. 117.

${ }^{13}$ Р. КАлЕв (Сунгуларе), Варианти на обредите Пеперуда и Герман, БФ 12.3, 1986, p. 47-58.

${ }^{14}$ Българска митология. Енциклопедичен речник, еd. А. Стойнев, София 1994, p. 255-256.

${ }_{15}$ Personal name of the deity, extent of the cult, cosmic image, cf. Й. Иванов, Культ Перуна у южных славян, ИОРЯС 8, 1904; А. GieYsztor, Mitologia Słowian, Warsaw 1980, p. 45-77. Cf.
} 
a companion of Perun and points to the Slavic prototype of the name Perperuna, coined on the base of the name of Perun by doubling the $\operatorname{root}^{16}$. A girl disguised as a frog can play the role of the wife of the lord of storms, whom people ask for the rain necessary for the crops to survive.

Frog accompanies Mother of God in other oral prose stories - for example in the Macedonian fairy tale Mother of God and the Frog, where the amphibian laments the death of Jesus and makes the weeping women laugh, including Mother of God:

Stay in health, my sister, Mother of God! May God keep you in his care. What are we to do when inexorable death comes? (...) Upon hearing the frog's speech even the dead would laugh, let alone the living. ${ }^{17}$

As G. Valchinova writes ${ }^{18}$, the frog, due to its relationship with water - a necessary component of the transition in the rituals of initiation - is a symbol of virginity, embedded in the folk consciousness from the earliest times, it can also be regarded as the embodiment of Virgin Mary herself.

Analysis of the content of Bulgarian ritual songs associated with Christmas and featuring the animal element yields the result in the form of a familiar theme, found also in prose works - namely, a curse placed on an animal (or a plant ${ }^{19}$ ). Punishing the disobedient representative of animal world is preceded by the situation of cosmic silence, during which all of nature is to worship the New-born by stopping any action. In $\mathrm{P}_{7}$, nature stops and grows silent, hoping to hear a song about the birth of God:

Койо чуло, се съпряло

Да послуша свети Петър,

Че му пее лична песен.

Мряна риба във дълбини

И тя чула, и тя спряла.

The singing reaches even the barbell in the deepest waters, which hears it and stops. Only the cuckoo and the aspen disobey and are cursed for breaking the ban. The theme of silencing all nature is also found in Bulgarian Christmas songs about

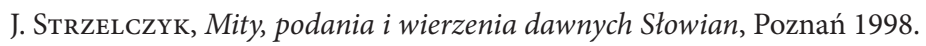

${ }^{16}$ A. Gieysztor, op. cit., p. 67.

${ }_{17}$ Cf. K. WrocŁaWsKI, O sposobie przyjmowania inspiracji Ewangelia (na podstawie macedońskiej legendy Bogurodzica i żaba), [in:] Biblia Slavorum Apocryphorum I. Vetus Testamentum, ed. G. Minczew, M. Skowronek, I. Petrov, Łódź 2009, p. 233-238.

${ }_{18}$ С. Г. ВълчиновА, Между езичество и християнство: свети Трифон в българските народни представи, БФ 15.2, 1989, р. 23.

${ }_{19}$ The theme of cursing the plant is far more prevalent in the Bulgarian folk song than cursing the animal. CHУH 60.1, 1993, lists the 37 song variants in which the Mother of God or one of the saints curses a plant (aspen, vetch, sycamore, rye, laurel, fir, and others), while only 5 in which an animal is cursed (cuckoo). 
the baptism of Jesus. ${ }^{20}$ Usually, it is St. John who orders all water and forests to stop, the sun is to stop scorching and the stars must cease their movement across the sky. In $\mathrm{P}_{7}$, Virgin Mary asks St. Peter to sing songs glorifying God's birth, and although the bird and the tree can hear the song, they remain unmoved by it. Mother of God curses them; the cuckoo may only use its voice in the spring, and after the feast of St. John, it has to be mute and blind. Similarly, in $\mathrm{P}_{5}$ the cuckoo makes a noise and wakes the Child. Virgin Mary curses the bird, to a certain extent projecting her own concerns and problems onto it. The cuckoo can never make its own nest, laying its eggs in some other bird's one. Then, its offspring will be recognised by the multi-coloured bird and thrown out of the nest:

Ой та тебе, Божне ле, кукувичке

Тъй да ходиш, Божне ле, да кукуваш

Да не виеш, Божне ле, вито гняздо

Най да снесеш, Божне ле, ф чуждо гняздо

Ф чуждо гняздо, Божне ле, пъстро яйце

Да го изведе, Божне ле, пъстра птичка

Да го изведе, Божне ле, да го отрани.

Similarly, in $\mathrm{P}_{6}$ Mother of God curses the bird, which explains that it just wanted to wake up shepherds who should mind their flock, but Mother of God shows it no understanding and curses the bird; it is allowed to make sound from the feast of St. George until the feast of St. John, and it has to remain silent for the rest of the year:

Проклела я Божа Майка

Ой та тебе, кукувичке;

Да кукуваш от Георгиов-ден,

От Георгиов-ден до Енюви-ден

От Енюви-ден да онемеш.

As A. Georgieva writes, it is important who casts the curse, as not everyone has such power ${ }^{21}$. Particularly powerful is the curse cast by a mother, who generally does it in order to defend her own children, the family homestead, or traditional values. A curse cast by a maiden is less potent, but maidens are often casting curses in folk songs, seeing as they are still outside the norms of the patriarchal collective and thus can act as their own will dictates. Virgin Mary is both a mother and a maiden in folk songs, so her curse, even if hastily cast, has a real power to bring misfortune on the cursed. And vice versa - a blessing bestowed by the Mother of God is a consequence of a particular situation and a reward for good behaviour, taking a particular form, such as fertility bestowed upon the cow.

\footnotetext{
${ }^{20}$ А.Т. ИлИЕв, Растителното ияарство в народната поезия, обичаите, обредите и поверията на българите, СНУНК 7, 1892, р. 385-386.

${ }^{21}$ А. ГЕоргИЕвА, Социална функция на клетвата в народната песен, БФ 8.1, 1982, р. 98-105.
} 
According to folk mythology, the cuckoo is a bird whose voice announces the arrival of spring and summer, and when it goes silent, it is a sign that summer has come to an end. Cuckoo can be heard from March 25 (Annunciation Day) until June 24 (feast of St. John) ${ }^{22}$. In songs, the bird receives punishment from Theotokos twice; it woke the sleeping Jesus with its singing so it has its voice taken away for most of the year, and it is forbidden from making a nest, so it cannot lay and hatch its young itself. Cuckoos is what single women are called: spinsters and widows, due to the biological characteristics of the bird, which is always alone in nature, never making its own nest ${ }^{23}$. Among the Bulgarian etiological legends, there is a story about a woman who has no food to feed her their children, so she asks God to turn her into a cuckoo. God obliges, and the children are abandoned and hungry. In other stories, children are turned into birds: the brother into an eagle owl and the sister - into a cuckoo. In yet another one - the sister is taking care of her wounded brother; she goes to get water and gets lost on her way, so she asks God to turn her into a cuckoo so that she would be able to see her brother from above. In Macedonian folk legends, the cuckoo used to be an unhappy woman who lost her brother (brothers) or son (children) and asked God to turn her into a bird. In another tale, the sister locks herself in a house with her dead brother for six weeks before the Annunciation feast, and spends all that time coo-cooing - lamenting. On the sixth Sunday, she flew out of the house already as a cuckoo ${ }^{24}$.

Analysis of folk beliefs relating to the cuckoo ${ }^{25}$ unearths new meanings of the curse cast by the Mother of God on the bird. In its basic sense, the curse is, of course, the result of the mother's anger with a creature that woke her child. However, as the voice of the cuckoo can be a harbinger of tragic events, it is natural to associate it with a prophecy of the martyrdom of Jesus ${ }^{26}$. The first song of a cuckoo is an important date in the astronomical calendar - the bird announces the coming of summer and warm weather, but if the Mother of God orders it to be silent, it is probably still too early for good weather. A false announcement of good weather can have disastrous consequences for communities that relied on agriculture or for the hajduci, who might go to the forest before the frost is gone for good. In one folk song, the hajduci hear the voice of the cuckoo on the feast of the Annunciation, and three hundred youths set out to the Stara Planina. There,

\footnotetext{
${ }^{22}$ In other variants, the cuckoo bird remains silent from the feast of St. John until Easter, and it sings from the feast of St. George (May 6) until the feast of St. John, and so on, depending on the region. ${ }^{23}$ The convergence of Slavic beliefs and superstitions associated with the cuckoo, cf. M. ZowCZAK, op. cit., p. 109-114; cuckoo in Polish folk beliefs: E. Majewski, Kukułka w mowie, pieśni i pojęciach ludu naszego, Wi 12, 1898, p. 385-408.

${ }^{24}$ Т. ВРАЖИНОВСКИ, Народна митологија на Македонциче, Скопје-Прилеп 1998, p. 135-137.

${ }_{25}$ С. И. ТодоровА, Кукувицата в българската фолклорна култура (Реблекси на митологичното мислене), ГААЕФО 10, 2012, р. 231-252; А.В. ГУРА, Символика животних в славянской народной традиции, Москва 1997.

${ }^{26}$ Associating the moment of birth with the death of Jesus in oral culture: M. ZowCzAK, op. cit., p. 250.
} 
they are caught by snow and frost. The hajduci die from the cold, deceived by the voice of the bird heralding spring ${ }^{27}$.

In some texts, the cuckoo can be interpreted as a personification of the Mother of God herself. A single woman who does not comply with societal norms is just like a wild bird that does not make its own nest and abandons its eggs in other birds' ones:

\footnotetext{
Префръкнала, Божне ле, пъстра птичка през горица, Божне ле, през зелена, над водица, Божне ле, над студена. Не ми било, Божне ле, пъстра птичка, най ми била, Божне ле, Божя майка. $\left(\mathrm{P}_{5}\right)$
}

In more archaic versions of the song, the Mother of God was probably replaced by a cuckoo or a samovila - a number of images that survived in poetic works despite the influence of the Christian religion seems to prove it: the Mother of God with her child in the forest, in the nature, hanging a cradle on a tall tree (The Tree of Life, from which the bird is watching the fate of the world), a sense of unity, and even control over nature. The cuckoo's song both awakens life and announces its end, with reference to the transience of the seasons, associated with the nature succumbing to sleep after the harvest is finished and the crops are reaped.

In certain Bulgarian carolling songs it is the animals that announce the happy tidings that Christ is born to the world $\left(\mathrm{P}_{1}, \mathrm{P}_{2}\right)$. In the quoted texts, this honourable task is carried out by the doves - symbols of purity and innocence, but also sacrificial animals, offered as a sign of purification of women after childbirth, as the canonical Gospels describe - Mary and Joseph come to the temple, to offer a sacrifice according to what is said in the law of the Lord, a pair of turtledoves, or two young pigeons ${ }^{28}$. In Christian iconography the dove dominates as a symbol of the Holy Spirit, present at the baptism of Jesus, and goldsmiths make vessels in the shape of a dove to store the host or the sacred oils, as well as emblems in the form of pendants placed in baptismal chapels, and other such objects ${ }^{29}$.

In Bulgarian carolling songs, pigeons or doves are presented as creatures close to the higher, divine world and heaven. K.A. Shapkarev sees the figure of the grey dove featured in the song as the Mother of God herself. In $\mathrm{P}_{2}$, a pair of pigeons bring walnut twigs to a goldsmith so that the artisan would make golden keys out of them to open heaven. The opening heavens is of major importance here - On special holidays, spheres of the world come together: the heaven opens up to people, but only a select few can see $i t^{30}$. In the cited song, the birth of Jesus,

\footnotetext{
${ }^{27}$ А.Т. ИлиЕв, op. cit., p. 357-360.

${ }^{28}$ Lc 2, 24.

${ }^{29}$ D. Forstner, Świat symboliki chrześcijańskiej. Leksykon, trans. W. Zarzewska, P. Pachciarek, R. TuRzyŃski, Warszawa 1990, p. 228-232.

${ }^{30}$ M. ZowCZAK, op. cit., p. 450.
} 
in whose honour the skies open, is associated with the creation of the world, or rather its re-creation ${ }^{31}$. The coming of the Messiah is equal to the advent of a new order. Celebration of this momentous event is reminiscent of the biblical image of Arcadian order of things with Jesus reigning over all creatures, who pay him homage and live together in absolute harmony.

The belief in the presence of animals in the birthplace of Jesus, though firmly rooted in the minds of the people, is not confirmed in the words of the canonical Gospels of St. John, St. Matthew and St. Mark. However, the Gospel of St. Luke mentions shepherds at the manger: And in that region there were shepherds out in the field, keeping watch over their flock by night ${ }^{32}$.

The body of the South Slavonic Apocrypha includes a very popular Protoevangelium Iacobi, written in Greek in the second century AD, and translated into Slavonic in the eleventh or twelfth century, probably in Bulgaria. The piece is divided into three equivalent parts, which describe, respectively: the birth and exemplary childhood of Mary, then the choice of Joseph to be her husband, and finally the Annunciation and the Birth of Jesus, inspired by Matthew's and Luke's canonical tradition, as well as the flight of the Holy Family to Egypt. The second part of the Bulgarian title of the apocryphal text, Исус и Богородииа. Повест на архиепископ Яков Йерусалимски за рождението на Богородица преставната наша владичииа и вечнодева Мария, narrows down the scope of the work, emphasising its focus on the figure of the Mother of God. As Fr. M. Starowieyski writes, the Protoevangelium of James later became the basis for the Lives of Mary ${ }^{33}$. In the third part of the Apocrypha, Joseph and pregnant Mary go to the census. When the woman goes into labour, Joseph leaves her in a cave and heads to Bethlehem in search of a midwife. Then the man has a mystical vision of nature frozen in time and space:

Аз, Йосиф, изнемогнах от вървене и като погледнах небето, видях да стои там небесен кръг. И като погледнах към въздуха, зачудих се - птиците небесни бяха млъкнали. И погледнах към земята и видях един съд положен и работници насядали наоколо, а ръцете им протегнати към съда. Дъвчещите не дъвчеха, тези, които искаха да вземат нещо, не вземаха, тези, които искаха да сложат нещо в устата, не можеха да го внесат, а всички лица бяха обърнати нагоре. И видяха пасящите овце, които застанаха неподвижно; овчарят пое гегата, за да ги удари, а ръката му остана горе. И погледнах към течението на реката и видях козли и устите им не пасяха и не пиеха. След това всичко тръгна отново по своя път. ${ }^{34}$

\footnotetext{
${ }^{31}$ Cf. ibidem, p. 226.

${ }^{32}$ Lc $2,8$.

${ }_{33}$ Protoewangelia Jakuba, ed. et trans. M. Starowieyski, [in:] Apokryfy Nowego Testamentu. Ewangelie apokryficzne, vol. I, Fragmenty. Narodzenie i dzieciństwo Maryi i Jezusa, ed. IDEM, Kraków 2003 (cetera: Protoewangelia Jakuba), p. 267.

${ }^{34}$ New Bulgarian translation: Повест на архиепископ Яков Йерусалимски за рождението на Богородииа преславната наша владичица и вечнодева Мария, [in:] Стара българска титература, vol. I, Апокрифи, еd. Д. ПЕткАНовА, София 1981, p. 130 (based on the edition): П.А. ЛАвРОв, Апокрифичиские тексты, Санкт-Петербург 1899, р. 52-63.
} 
It seems that in anticipation of the birth of Jesus the whole world stood still: birds stopped mid-air, goats stood still at the waterhole, workers looked to the skies, stillness came over the shepherd and his sheep. The stylistic idea employed in the vision of Joseph was often used in ancient literature: the stillness of nature announces the presence of $\operatorname{God}^{35}$. The same situation is described in other apocryphal texts dealing with the childhood of Jesus, for example in The Book of the Birth of the Saviour, and Mary, and a Midwife, which is partly a Latin reworking of the Protoevangelium of James:

In that hour all became quiet with deep silence and awe. For even winds stopped and gave no breeze and not a single leaf on trees was stirred nor sound of waters heard; rivers did not flow, nor did the sea wave, and all the gushing waters grew silent; no human voice made a sound, and there was great silence. $^{36}$

Similar fragments also appear in other texts in Latin, for example in The Armenian Gospel of the Infancy. When Joseph goes in search of a midwife, he witnesses nature ceasing its natural activity in anticipation of the birth. The wind stops blowing, birds stop mid-flight, potter freezes over a vessel he is making, driven stock stops moving forward, camels gathered by a stream stop drinking, even a stick raised by a shepherd does not fall on rams ${ }^{37}$.

The animal element present in the description (sheep, goats, birds, camels) is only part of the background, there is no symbolic meaning in the situation The Book of the Birth of the Saviour, and Mary, and a Midwife makes no mention at all about the behaviour of animals during the Nativity of the Lord. It seems, however, that the cosmic silence may be one of the common themes found in the Bulgarian ritual songs and apocryphal texts ${ }^{38}$. In the examples of the Bulgarian oral poetry listed above, nature was to freeze, or to become absolutely silent while the Christmas songs were performed, which is expressed in a series of images showing the behaviour of fauna (mostly wild) and flora during miraculous events. The shepherd driving his flock featured in the apocryphal texts is also present in folklore, but somewhat outside the cosmic silence - he either takes the form of one of the saints, who takes care of the flock, or is depicted outside the main course of events, as the one who overslept and allowed the flock to wander too far, causing the cuckoo to fall out of grace with the Mother of God.

\footnotetext{
${ }^{35}$ Protoewangelia Jakuba, p. 283. Cf. M. ZowczAK, op. cit., 302.

${ }^{36}$ The Latin Infancy Gospel (Aroundel Form), [in:] The Apocryphal Gospels: Texts and Translations, ed. B. Ehrman, Z. Plese, New York 2011, p. 127.

${ }^{37}$ Ewangelia Dzieciństwa Ormiańska, ed. M. STARowieyski, trans. E. NowaK, [in:] Apokryfy Nowego Testamentu..., p. 471.

${ }^{38}$ The symbolism of the cosmic silence, of the frozen world (stasis) is also associated with magic ritual and ritual practice - cf. M. ZowcZAK, op. cit., p. 302-304, J.S. WAsilewski, Tabu, Warszawa 2010, p. 348-354.
} 
Another locus communes can be a popular theme of cursing a plant or an animal, exhibiting similar traits as some episodes also appearing in pseudo-canon literature; for example, in Infancy Gospel of Thomas. Written in the second century $\mathrm{AD}$, it became known in the cultural circle of the South Slavs from the tenth or eleventh century; it was preserved in six copies - each of them contain Bulgarian influence in the vocabulary, which led some researchers to point to Bulgaria as the place of its probable translation ${ }^{39}$. Детството на нашия господ, какрасна и как правеше чудеса (Томино евангелие) describes twelve episodes from the life of the Lord - missing from the story found in the canonical gospels. Several-years-old Jesus works miracles (...) cruel and often in poor taste $e^{40}$ : he makes birds out of clay and breathes life into them, takes the life from other children, chastises his father, but he also repairs the damage he had done previously. In the second episode, Jesus casts a curse on the son of Annas, who had upset him during a game. The child withers:

В това време синът на книжника Ананий беше там с баща му Йосиф. Той взе върбова пръчка и развали вирчето, което Исус беше направил; и водата изтече. Когато Исус видя вирчето развалено, не му стана добре. И му рече: Нечестиви и неразумни содомянино, какво ти пречи моето вирче и моята речиия? Още сега да изсъхнеш като дърво и да не даваш нито плод, нито листа. И в същия момент детето изсъхна. Като побягна, Исус си отиде в къщи, а родителите на отслабналия дойдоха, оплакаха младостта му и говореха на Йосифа: Такова ли дете имаш. ${ }^{41}$

In the Gospel of St. Mark, there is a parable about a barren fig tree, the fruit of which the weary Jesus wanted to pick. Unfortunately, the only thing the tree had to offer were leaves, so Jesus cursed it and the fig tree immediately withered ${ }^{42}$.

In the Bulgarian folk culture the person casting the curse is Virgin Mary, one of the saints, or God himself, and approaches the theme of Jesus' childhood in a limited scope (always from the point of view of the Mother of God), never making the Lord cast the curse. The similarity of the theme of cursing animal and plant in the folk culture and the Apocrypha has been pointed out many times by scholars, with other sources being The Golden Legend and medieval novellas ${ }^{43}$.

The quoted texts of the Bulgarian oral culture referring to the theme of the Nativity of the Lord, the Gospel inspiration or even interaction with the apocryphal text fades into the background. The biblical message is dominated by the mythological ${ }^{44}$ aspect of the storyline, allowing minor modifications or references

\footnotetext{
${ }^{39}$ Dzieciństwo Pana, Ewangelia Tomasza (Dzieciństwa), ed. et trans. M. StarowiEyski, [in:] Apokryfy Nowego Testamentu..., p. 388-404.

${ }^{40}$ An opinion of M. Starowieyski - ibidem, p. 388.

${ }^{41}$ New Bulgarian translation: Детството на нашия господ, как расна и как правеше чудеса, [in:] Стара българска литература..., p. 138 (based on several collections).

${ }^{42}$ Mc 11, 12-14.

${ }^{43}$ Cf. comment to $\mathrm{P}_{7}$ in $\mathrm{CHYH} 60$.

${ }^{44}$ Meaning: the first period of the Bulgarians' arrival in the Balkan Peninsula, before the ninth century.
} 
in terms of the events described. ${ }^{45}$ The content of the stories and folk songs is primordial in relation to the processed content of the Gospel; biblical characters and situations are introduced to oral stories already in circulation, creating texts that are testament of the so-called folk Christianity.

The excerpted texts of fairy tales and legends clearly marginalise the theme of the Divine Birth, focusing on the figure of the Mother of God and her actions: meeting with St. Tryphon, rejecting the child, receiving lessons on motherhood from the frog, escaping with the Child to Egypt. The birth of Jesus is used as an excuse to tell a story of an etiological character, often based on ritual custom and referring to it, such as clipping vines. The theme of cursing animal or plant occurs both in the canonical Scripture, as well as in the apocryphal works.

In the quoted songs performed during Christmas, the events of the Bethlehem Night and the related characters are presented as part of the wildlife and part of nature. Carolling songs paint a picture of a frozen world, of nature falling asleep while Jesus is sleeping, of a golden cradle hanging on the tree as a replacement of a manger, or folk saints appearing in the place of shepherds and the Magi. Just as in the case of fairy tales and legends, folk song uses the birth of Jesus to explain the genesis of some of the characteristics and phenomena of nature. Presentation of animals in ritual songs occasionally refers to the economic sphere (the shepherds slept, and their flock wandered away), while wild animals are the object of punishment or reward. This model is not observed in songs about representatives of the biblical avifauna ${ }^{46}$ - pigeons announcing the happy tidings of Christ's birth and making an oath to serve the Young God.

The Apocrypha known among the South Slavs mention animals in situations encountered also in the Bulgarian oral literature - the cosmic silence when fauna and flora freezes in anticipation of the birth of the Young God.

Translated by Katarzyna Gucio

\begin{abstract}
The article attempts to extract textual and extratextual planes on which representatives of fauna made their mark in the folklore of the South Slavs, mainly Bulgarians; in their oral literature, rituals, and beliefs, juxtaposed with selected Apocrypha, primarily from the Protoevangelium of James, confronted with the Scripture. The analysed texts (legends, folk tales, ritual songs performed during Christmas) relate to the birth of Christ in Bethlehem and placing him in a manger - the events of Night of Bethlehem and the flight of the Holy Family to Egypt.

The excerpted texts of fairy tales and legends marginalise the theme of the Divine Birth, focusing on the figure of the Mother of God and her actions: meeting with St. Tryphon, rejecting the child, receiving lessons on motherhood from the frog, escaping with the Child to Egypt. The birth of Jesus is used as an excuse to tell a story of an etiological character (theme cursing animal or plant),
\end{abstract}

\footnotetext{
${ }^{45}$ Reference to K. WrocŁaWsKi, op. cit., p. 233-238.

${ }^{46}$ S. Koziara, Losy frazeologizmów biblijnych z nazwami ptaków w języku polskim, [in:] Z problemów przekładu i stosunków międzyjęzykowych, vol. II, ed. T. ŻeBereK, T. BorUCKI, Kraków 2002, p. 191.
} 
often based on ritual custom and referring to it, such as clipping vines. Just as in the case of fairy tales and legends, folk song uses the birth of Jesus to explain the genesis of some of the characteristics and phenomena of nature. Presentation of animals in ritual songs occasionally refers to the economic sphere (the shepherds slept, and their flock wandered away), while wild animals are the object of punishment or reward. The Apocrypha known among the South Slavs mention animals in situations encountered also in the Bulgarian oral literature - the cosmic silence when fauna and flora freezes in anticipation of the birth of the Young God.

The quoted texts of the Bulgarian oral culture referring to the theme of the Nativity of the Lord, the Gospel inspiration or even interaction with the apocryphal text fades into the background. The content of the stories and folk songs seems to be primordial in relation to the processed content of the Gospel; biblical characters and situations are introduced to oral stories already in circulation, creating texts that are testament of the so-called folk Christianity.

Keywords: Nativity in folklore, etiological legend, fauna in oral culture, Holy Mother's curse, cosmic silence

Karolina Krzeszewska

Waldemar Ceran Research Centre for the History and Culture of the Mediterranean Area and South-East Europe PL - 90-237 Łódź, ul. Jana Matejki 32/38, pok. 209 karolina.krzeszewska@gmail.com 